\title{
EFEK IMPLANTASI ION Mg DAN Y TERHADAP SIFAT KETAHANAN OKSIDASI MATERIAL MA 956
}

\author{
B.A. Tjipto Sujitno, Lely Susita, RM, Suprapto \\ Pusat Penelitian Dan Pengembangan Teknologi Maju, Badan Tenaga Nuktir Nasional \\ Jl. Babarsari Kotak Pos 1008, Yogyakarta 55010
}

\begin{abstract}
ABSTRAK
EFEK IMPLANTASI ION Mg DAN Y TERHADAP SIFAT KETAHANAN OKSIDASI MATERIAL MA 956. Dalam makalah ini disajikan hasil penelitian tentang pengaruh implantasi ion Magnesium dan Yttrium terhadap sifat ketahanan oksidasi material MA 956. Untuk maksud tersebut material MA 956 diimplantasi dengan ion Magnesium dan Yttrium pada doses Ion $1 \times 10^{17} \mathrm{ion} / \mathrm{cm}^{2}$ dan pada energi 100 $\mathrm{keV}$. Untuk mengetahui pengaruh sifat ketahanan oksidasinya, sampel dipanasi pada temperatur 1100 ${ }^{\circ} \mathrm{C}$ dalam udara yang mengandung oksigen selama 100 jam dengan menggunakan TGA (Thermogravitymetry). Disamping itu juga telah dilakukan analisa struktur mikro menggunakan SEM dan analisa komposisi kimia menggunakan EDX, dari pengujian yang telah dilakukan diperoleh hasil bahwa untuk benda uji yang tanpa diimplantasi, untuk benda uji yang diimplantasi dengan ion Magnesium dan dengan ion Yttrium dengan waktu oksidasi 100 jam, laju oksidasinya masing-masing sekitar $0.54 \mathrm{mg} / \mathrm{cm}^{2}$., $0,48 \mathrm{mg} / \mathrm{cm}^{2}$ dan $0,40 \mathrm{mg} / \mathrm{cm}^{2}$. Sedangkan dari analisa struktur mikro potongan melintang terlihat bahwa ketebalan lapisan oksida masing-masing adalah sekitar $067 \mu \mathrm{m}$. 0,3 $\mu \mathrm{m}$ dan $0,25 \mu \mathrm{m}$. Dari hasil tersebut dapat disimpulkan bahwa dengan adanya implantasi elemen reakif Magnesium maupun Yttrium mampu menghambat laju oksidasi dari $0,54 \mathrm{mg} / \mathrm{cm}^{2}$ menjadi $0,48 \mathrm{mg} / \mathrm{cm}^{2}$ untuk material yang diimplantasi dengan ion Magnesium dan dari $0,54 \mathrm{mg} / \mathrm{cm}^{2}$, meyadi $0,40 \mathrm{mg} / \mathrm{cm}^{2}$ untuk materialyang diimplantasi dengan ion Yttrium.
\end{abstract}

\section{ABSTRACT}

EFFECT OF Mg DAN Y IONS IMPLANTATION ON THE OXIDATION RESISTANCE OF MA 956 MATERIALS. Effect of implanted Yttrium and Magnesium ions on the oxidation behaviour of MA 956 materials are presented in this paper. For this purpose, magnesium and yttrium ions have been implanted into MA 956 materials for ion dose $1 \times 10^{17}$ ion/ $\mathrm{cm}^{2}$ and energy $100 \mathrm{keV}$. Effect of oxidation resistance on the un-implanted and implanted materials was observed by heating the material in oxygen environment at temperature $1100^{\circ} \mathrm{C}$ for 100 hours using TGA apparatures. Besides that, it has been observed the cross section microstructures and chemical analysis using SEM coupled with EDAX. It's found that for 100 hours oxidation time, the oxidation rate were $0.54 \mathrm{mg} / \mathrm{cm}^{2}, 0,48 \mathrm{mg} / \mathrm{cm}^{2}$ dan $0,40 \mathrm{mg} / \mathrm{cm}^{2}$, respectively. From cross section microstructures analysis, the thickness of the oxide layers were $0.67 \mu \mathrm{m} 0.3 \mu \mathrm{m}$ and $0.25 \mu \mathrm{m}$. From these data, it can be concluded that the implantation of Magnesium and Yttrium can improve the oxidation resistance of MA 956 materials.

\section{PENDAHULUAN}

$\mathrm{P}$ enelitian perlakuan permukaan melalui coating, implantasi ion dan ion beam mixing dengan elemen reaktif seperti misalnya yttrium dan cerium telah banyak dilakukan di berbagai pusat penelitian di dunia. Adanya pengaruh positip elemen reaktif terhadap material temperatur tinggi dan belum jelasnya mekanisme pengaruh tersebut, hingga saat ini masih merupakan masalah yang sangat menarik untuk diteliti dan diaplikasikan diberbagai keperluan teknik.

Perlakuan permukaan dengan implantasi ion yttrium dan magnesium pada paduan MA 956 diharapkan dapat digunakan sebagai metoda untuk menghambat laju tumbuhnya lapisan oksida yang terbentuk khususnya $\mathrm{Al}_{2} \mathrm{O}_{3}$, sehingga terbentuk 
lapisan proteksi yang akhirnya dapat memperpanjang umur operasi paduan yang digunakan. (3)

Paduan super MA 956 (Mechanical Alloys) adalah paduan ODS (Oxid Dispersion Strengthened) merupakan satu diantara kandidat-kandidat bahan untuk komponen pada temperatur tinggi misalnya penukar panas, turbin dan, ruang pembakaran pada mesin bakar.

Paduan ODS biasanya dibuat dengan mesin penggiling serbuk energi tinggi yang dicampur elemen paduan dasar dengan oksida dispersi. Serbuk paduan didapatkan dengan teknik HIP (Hot isostatic Pressing) untuk dibentuk batangan silinder yang nantinya dipotong dalam bentuk sampel-sampel kecil sebagai benda uji.

Paduan MA 956 dengan komposisi $74,7 \% \mathrm{Fe}, 20 \% \mathrm{Cr}, 4,5 \% \mathrm{Al}, 0,3 \%$ Ti dan $0,5 \% \mathrm{Y}_{2} \mathrm{O}_{3}$ (\% berat) biasanya merupakan bahan logam yang tahan terhadap oksidasi karena adanya lapisan protektif pada permukaan yang terbentuk secara alami saat operasi temperatur tinggi yaitu lapisan alumina $\left(\mathrm{Al}_{2} \mathrm{O}_{3}\right)$. Lapisan tersebut berkembang sangat lambat dan mempunyai kestabilan termodinamik sangat baik. Selain itu adanya lapisan alumina dapat menghambat tembusan tritium yang dapat membahayakan lingkungan terutama pada sistem reaktor temperatur tinggi ${ }^{(5-6)}$

Walaupun material MA 956 merupakan material yang tahan terhadap suhu tinggi, tetapi karena adanya beban siklus termal selama beroperasi ataupun beban mekanik saat diperbaiki maka lapisan proteksi yang telah terbentuk tersebut akan mudah mengelupas. Untuk mengatasi masalah tersebut, telah banyak penelitian dilakukan yaitu dengan, menambah elemen reaktif seperti yttrium sebesar $0,1 \mathrm{~s} / \mathrm{d} 1 \%$ dalam bentuk logam atau oksida dispersi dan pada ketebalan dalam orde $500 \AA$. Paduan tersebut secara termodinamis menjadi lebih stabil dari pada partikel-partikel penguatnya seperti "gamma prime" $\left(\gamma^{\prime}\right)$ dan karbida yang ada pada padatan temperatur tinggi konvensional. Oleh karena itu kekuatannya ditunjang oleh oksida-oksida dispersi untuk menopang operasi temperatur tinggi, karena pembesaran atau disolusi partikel-partikel tidak terjadi. Selain itu dengan adanya dispersi akan menstabilisasi struktur mikro dari paduan menjadi sangat halus pada operasi yang sangat lama sehingga menjadi tahan terhadap penjalaran keretakan ${ }^{(7)}$

Dalam tulisan ini dilaporkan hasil penelitian tentang pengaruh penambahan ion yttrium dan magnesium pada material MA 956 yang diimplantasikan pada dosis $1 \times 10^{18}$ ion $/ \mathrm{cm}^{2}$ pada energi $100 \mathrm{keV}$ terhadap sifat ketahanan oksidasi pada temperatur $1100^{\circ} \mathrm{C}$ selama 100 jam. Disamping itu juga disajikan hasil pengamatan struktur mikro dengan menggunakan SEM dan analisa unsur menggunakan EDAXS.

\section{TATA KERJA DAN PERCOBAAN}

Bahan penelitian yang digunakan adalah paduan MA 956 dengan komposisi kimia Fe-20Cr-4,5Al-3Ti- $0,5 \mathrm{Y}_{2} \mathrm{O}_{3}$. Benda uji yang berbentuk silinder dengan diameter $10 \mathrm{~mm}$ dan tebal $2 \mathrm{~mm}$, pada salah satu permukaannya digosok hingga halus dan mengkilap seperti cermin. Setelah proses penghalusan selesai kemudian dilanjutkan dengan proses pencucian dengan menggunakan aseton untuk menghilangkan kotoran dan lemak yang mungkin terdapat pada permukaan benda uji menggunakan pencuci ultrasonic (ultrasonic cleaner).

Setelah tahap persiapan cuplikan selesai, tahap berikutnya adalah proses doping elemen reaktif yttrium dan magnesium dengan kemumian 99,998 \% menggunakan teknik implantasi ion. Mesin implantasi ion yang digunakan adalah akselerator energi rendah jenis Cocroft-Walton buatan P3TM-BATAN yang mampu mempercepat berbagai jenis ion. Pada penelitian ini, implantasi ion dilakukan pada dosis ion $1 \times 10^{18} \mathrm{ion} / \mathrm{cm}^{2}$ dan energi $100 \mathrm{keV}$ dengan pertimbangan bahwa dengan dosis dan energi tersebut prosentase 
yang terimplantasi sudah dalam orde 0,1 $<\%<1$. dan ketebalan dalam orde $480 \mathrm{~A}$.

Untuk menguji keberhasilan proses, telah dilakukan uji oksidasi suhu tinggi menggunakan peralatan TGA, pengamatan struktur mikro dengan SEM dan analisa komposisi kimia dengan EDX. Uji ketahanan oksidasi dilakukan secara isothermal pada suhu $1100^{\circ} \mathrm{C}$ selama 100 jam, baik untuk benda uji referensi (benda uji yang tidak diimplantasi) maupun untuk benda uji yang diimplantasi dengan ion Magnesium maupun yttrium.

\section{HASIL DAN PEMBAHASAN}

Hasil uji ketahanan oksidasi suhu tinggi dengan TGA pada suhu $1100{ }^{\circ} \mathrm{C}$ dalam lingkungan udara yang mengandung oksigen selama 100 jam untuk benda uji matrial MA 956 yang tanpa diimplantasi dan untuk benda uji yang diimplantasi dengan ion magnesium dan yttrium pada dosis ion $1 \times 10^{17} \mathrm{ion} / \mathrm{cm}^{2}$ dan pada energi $100 \mathrm{keV}$ disajikan pada Gambar 1.

Gambar 2 menyajikan (a) tampang lintang struktur mikro hasil pengamatan menggunakan SEM dari cuplikan material MA 956 setelah proses oksidasi selama 100 jam pada suhu $1100{ }^{\circ} \mathrm{C}$, (a) tanpa implantasi, (b) diimplantasi dengan ion magnesium (Mg), (c) diimplantasi dengan ion yttrium (Y) masing-masing pada dosis $1 \times 10^{18}$ ion $/ \mathrm{cm}^{2}$ dan energi $100 \mathrm{keV}$.

Gambar 3 menyajikan (a) tampang lintang struktur mikro hasil pengamatan menggunakan SEM dari cuplikan material MA 956 tanpa implantasi setelah proses oksidasi selama 100 jam pada suhu $1100{ }^{\circ} \mathrm{C}$. (b) spektrum EDX pada lapisan oksida. Gambar 4 menyajikan (a) tampang lintang struktur mikro hasil pengamatan menggunakan SEM dari cuplikan material MA 956 setelah proses oksidasi selama 100 jam pada suhu $1100{ }^{\circ} \mathrm{C}$ yang diimplantasi dengan ion yttrium $(\mathrm{Y})$ pada dosis $1 \times 10^{18}$ ion $/ \mathrm{cm}^{2}$ dan energi $100 \mathrm{keV}$. (b) Spektrum EDX pada lapisan paling atas dari lapisan oksida.
Gambar 5 menyajikan (a) tampang lintang struktur mikro hasil pengamatan menggunakan SEM dari cuplikan material MA 956 setelah proses oksidasi selama 100 jam pada suhu $1100{ }^{\circ} \mathrm{C}$ yang diimplantasi dengan ion yttrium $(\mathrm{Y})$ pada dosis $1 \times 10^{18}$ ion $/ \mathrm{cm}^{2}$ dan energi $100 \mathrm{keV}$ (b) spektum EDX pada lapisan oksida (c) spektrum EDX pada lapisan SEM antar (inter face) lapisan (d) spektrum EDX dari lapisan induk (substrat). Sedangkan Gambar 6 menyajikan (a) tampang lintang struktur mikro hasil pengamatan menggunakan SEM dari cuplikan material MA 956 setelah proses oksidasi selama 100 jam pada suhu $1100{ }^{\circ} \mathrm{C}$ yang diimplantasi dengan ion magnesium $(\mathrm{Mg})$ pada dosis $1 \times 10^{18} \mathrm{ion} / \mathrm{cm}^{2}$ dan energi $100 \mathrm{keV}$ (b) spektrum EDX pada lapisan paling atas dari lapisan oksida.

Dari Gambar 1. yang menggambarkan antara perubahan massa persatuan luas (sumbu tegak) dan lamanya proses oksidasi dalam satuan waktu (sumbu datar) terlihat ada 3 kurve yang masing-masing menggambarkan (1) untuk cuplikan yang tidak diimplantasi, (2) untuk cuplikan yang diimplantasi dengan ion magnesium $(\mathrm{Mg})$ dan (3) untuk cuplikan yang diimplantasi dengan ion yttrium (Y). Dari ketiga kurve tersebut terlihat bahwa setelah proses oksidasi isothermal pada suhu $1100{ }^{\circ} \mathrm{C}$ selama 100 jam, laju oksidasinya masing-masing adalah sekitar $0,54 \mathrm{mg} / \mathrm{cm}^{2}$, $0,48 \mathrm{mg} / \mathrm{cm}^{2}$ dan $0,40 \mathrm{mg} / \mathrm{cm}^{2}$. Peningkatan sifat ketahanan oksidasi tersebut dimungkinkan oleh terbentuknya oksidaoksida logam yang lebih merata dan stabil akibat dari penambahan ion $\mathrm{Mg}$ ataupun $\mathrm{Y}$. Dari hasil tersebut dapat disimpulkan bahwa dengan adanya penambahan elemen reaktif magnesium maupun yttrium ternyata mampu meningkatkan ketahanan oksidasi material MA 956.

Sedangkan dari analisa struktur mikro potongan melintang yang disajikan pada Gambar 2 a, b, c, atau Gambar 3a, atau Gambar 4 a, atau Gambar 5a, terlihat bahwa ketebalan lapisan oksida masing-masing 
cuplikan adalah sekitar $0,67 \mu \mathrm{m}, 0,3 \mu \mathrm{m}$ dan $0,25 \mu \mathrm{m}$.. Dari data tersebut juga terlihat bahwa dengan penambahan yttrium (Y) lebih efektif dalam hal menahan laju oksidasi dibandingkan dengan penambahan $\mathrm{Mg}$, yang hal ini juga mengindikasikan bahwa efek penambahan untuk masing-masing jenis ion juga berbeda.

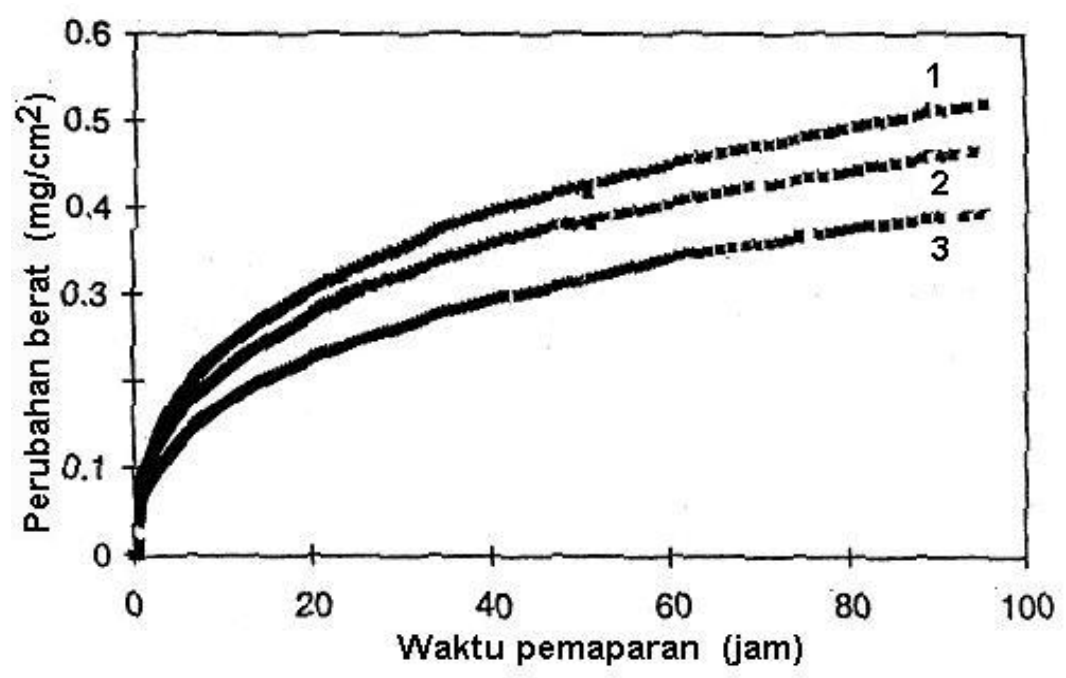

Gambar 1. Hasil uji ketahanan oksidasi suhu tinggi dengan TGA pada suhu $1100{ }^{\circ} \mathrm{C}$ dalam lingkungan udara yang mengandung oksigen selama 100 jam. Kurve I adalah cuplikan tanpa implantasi (referensi), sedangkan kurve 2 dan 3 masing-masing setelah dilakukan implantasi dengan ion magnesium $(\mathrm{Mg})$ dan yttrium $(\mathrm{Y})$ pada dosis ion $1 \times 10^{18} \mathrm{ion} / \mathrm{cm}^{2}$ dan energi ion $100 \mathrm{keV}$. 


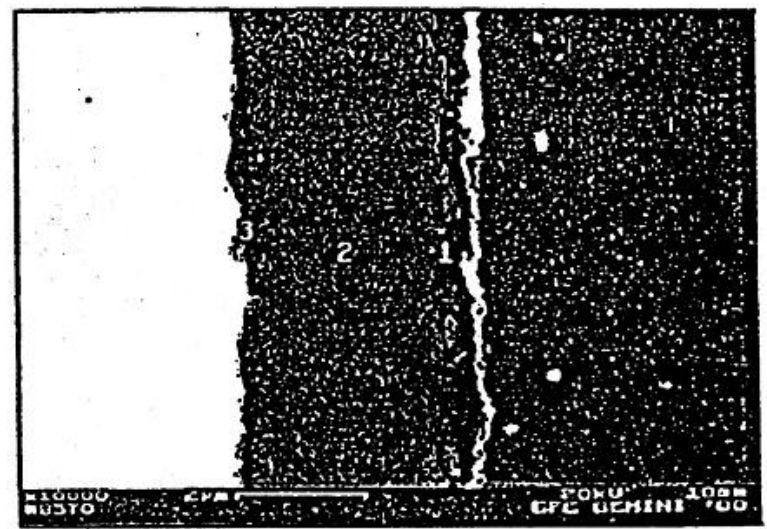

(a)

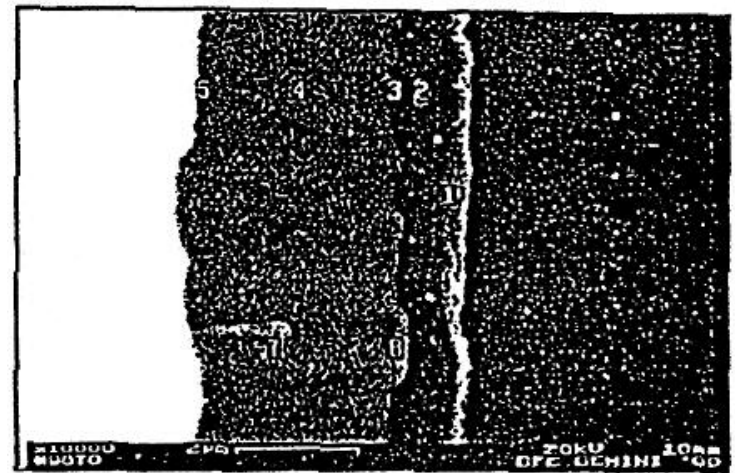

(b)

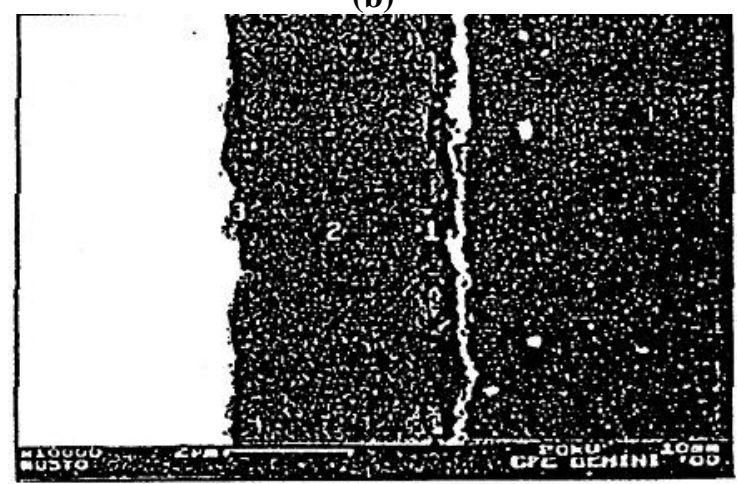

(c)

Gambar 2. Tampang lintang struktur mikro hasil pengamatan menggunakan SEM dari cuplikan material MA 956 setelah proses oksidasi selama 100 jam pada suhu $1100{ }^{\circ} \mathrm{C}$, (a) tanpa implantasi, (b) diimplantasi dengan ion magnesium $(\mathrm{Mg})$, (c) diimplantasi dengan ion yttrium (Y) masing-masing pada dosis $1 \times 10^{18} \mathrm{ion} / \mathrm{cm}^{2}$ dan energi $100 \mathrm{ke} \mathrm{V}$. 


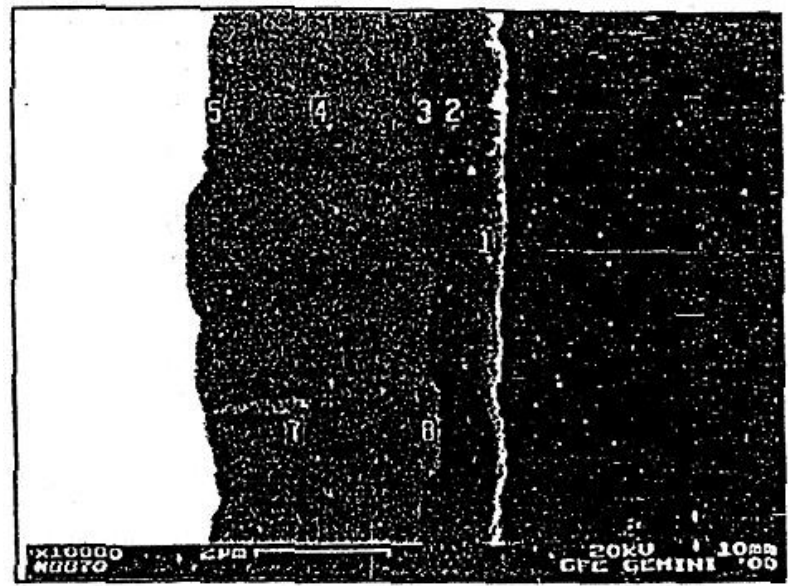

(a)

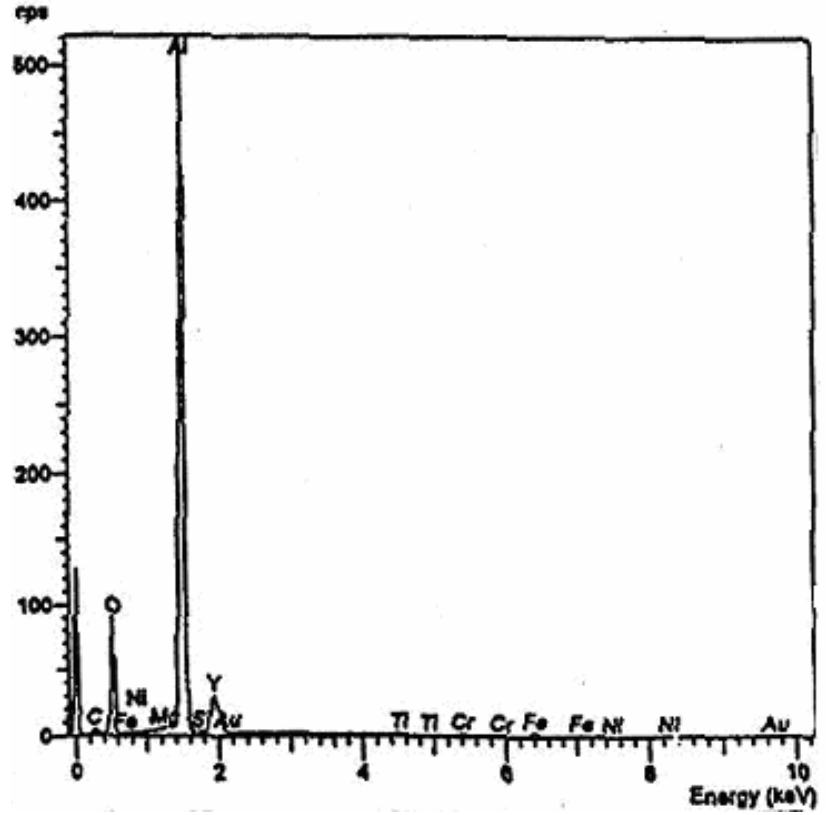

(b)

Gambar 3. (a) Tampang lintang struktur mikro hasil pengamatan menggunakan SEM dari cuplikan material MA 956 tanpa implantasi setelah proses oksidasi selama 100 jam pada suhu $1100{ }^{\circ} \mathrm{C}$ (b) Spektrum EDX pada lapisan oksida. 


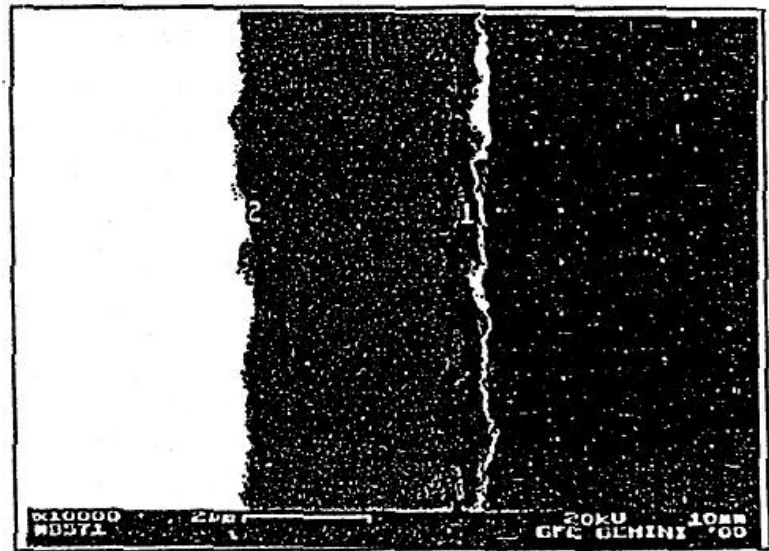

(a)

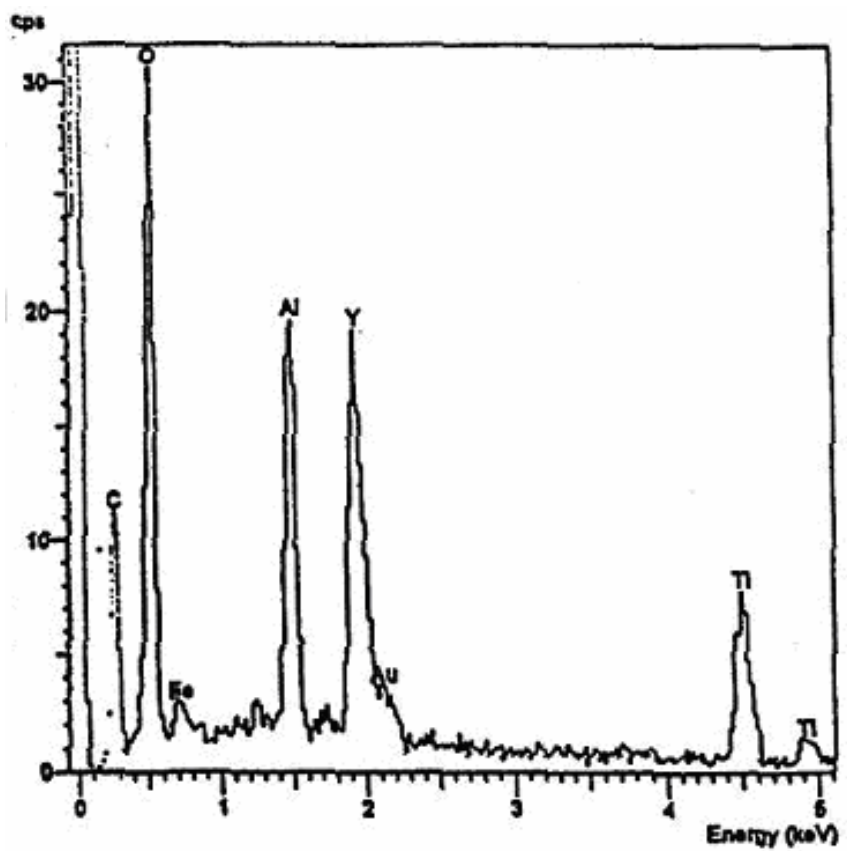

(b)

Gambar 4. (a) Tampang lintang struktur mikro hasil pengamatan menggunakan SEM dari cuplikan material MA 956 setelah proses oksidasi selama 100 jam pada suhu $1100{ }^{\circ} \mathrm{C}$ yang diimplantasi dengan ion yttrium (Y) pada dosis $1 \times 10^{18} \mathrm{ion} / \mathrm{cm}^{2}$ dan energi ion $100 \mathrm{keV}$. (b) Spektrum EDX pada lapisan paling atas dari lapisan oksida. 


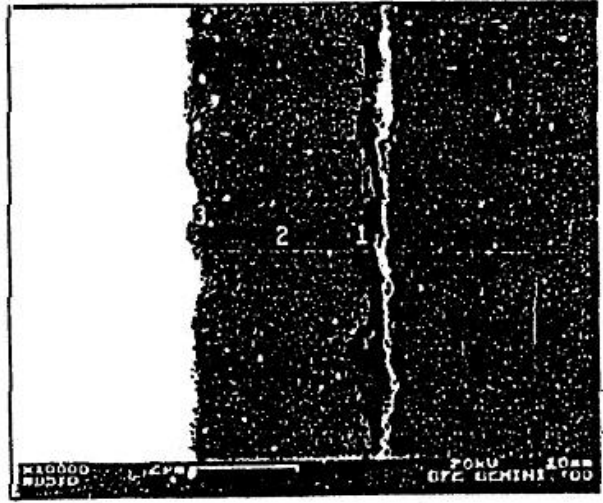

(a)

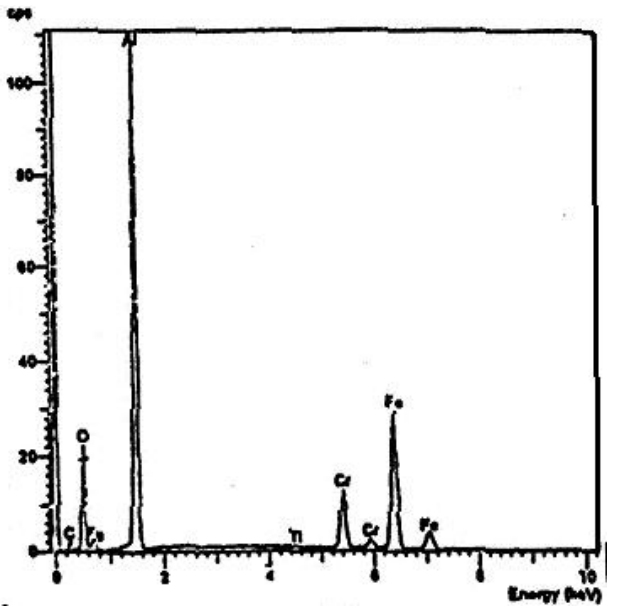

(c)

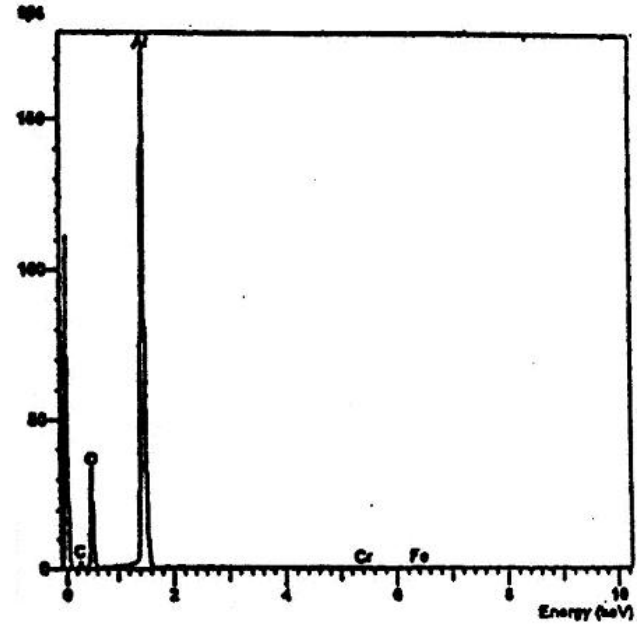

(b)

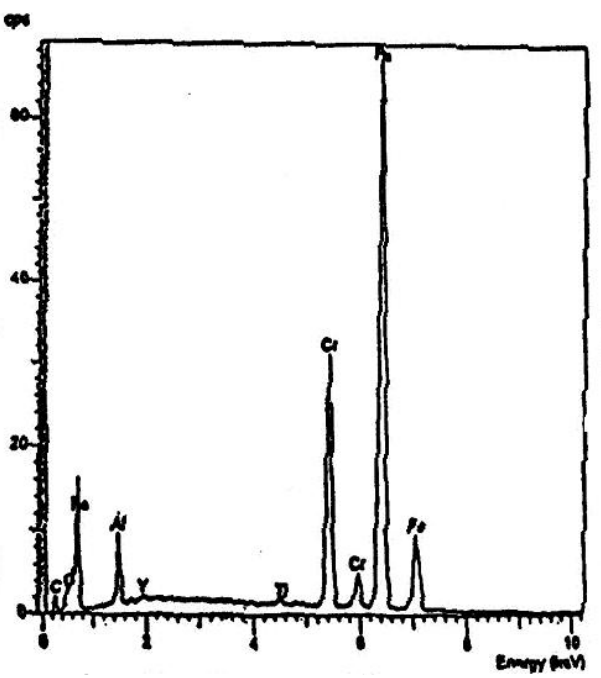

(d)

Gambar 5. (a) Tampang lintang struktur mikro hasil pengamatan menggunakan SEM dari cuplikan material MA 956 setelah proses oksidasi selama 100 jam pada suhu $1100{ }^{\circ} \mathrm{C}$ yang diimplantasi dengan ion yttrium (y) pada dosis $1 \times 10^{18} \mathrm{ion} / \mathrm{cm}^{2}$ dan energi ion $100 \mathrm{keV}$, (b) Spektrum EDX pada lapisan oksida (c) Spektrum EDX pada lapisan antar (interface) lapisan, (d). Spektrum EDX dari lapisan induk (substrat). 


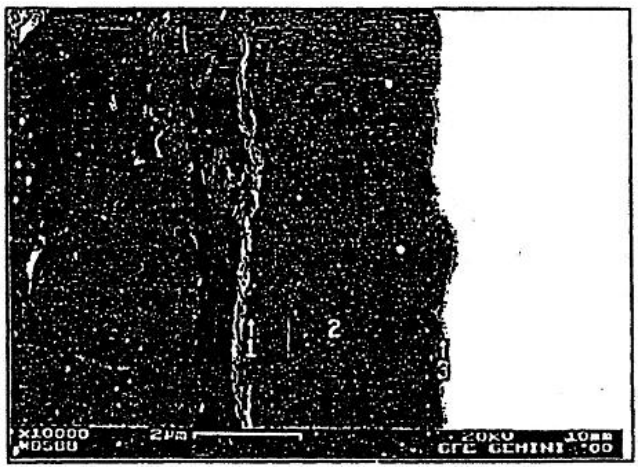

(a)

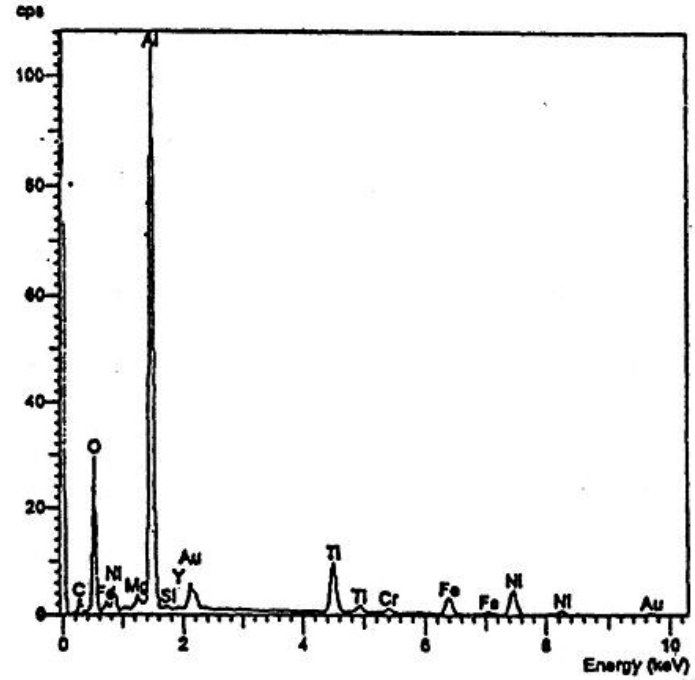

(b)

Gambar 6. (a) Tampang lintang struktur mikro hasil pengamatan menggunakan SEM dari cuplikan material MA 956 setelah proses oksidasi selama 100 jam pada suhu $1100{ }^{\circ} \mathrm{C}$ yang diimplantasi dengan ion magnesium $(\mathrm{Mg})$ pada dosis $1 \times 10^{18}$ ion $/ \mathrm{cm}^{2}$ dan energi ion $100 \mathrm{keV}$, (b) Spektrum EDX pada lapisan paling atas dari lapisan oksida.

Dari spektrum EDX Gambar 3b, 4b, $5 \mathrm{~b}, 5 \mathrm{c}, \quad 5 \mathrm{~d}$ maupun Gambar $6 \mathrm{~b}$ yang mengambarkan kompisisi kimia untuk masing-masing cuplikan pada lapisan oksida, pada lapisan oksida paling atas, pada lapisan antar muka maupun pada material induknya terlihat bahwa distribusinya konsentrasi untuk masing-masing unsur berbeda. Untuk cuplikan yang tanpa diimplantasi, setelah dioksidasi isothermal pada temperatur 1100 ${ }^{\circ} \mathrm{C}$ selama 100 jam ternyata unsur-unsur pembentuk oksida tidak teramati. Sedangkan untuk cuplikan yang telah diimplantasi dengan ion magnesium ataupun yttrium ternyata unsur-unsur pembentuk oksida seperti $\mathrm{Cr}$, Ti, Ni dan Fe ternyata muncul di permukaan dan semakin kedalam intensitasnya (prosentase) semakin berkurang hal tersebut menunjukkan bahwa dengan adanya penambahan elemen seperti $\mathrm{Y}$ dan $\mathrm{Mg}$ memacu keluarnya unsur-unsur 
material induk untuk berdifusi kepermukaan untuk membentuk oksida.

\section{KESIMPULAN}

Dari hasil penelitian yang telah dilakukan dapat diambil beberapa kesimpulan :

$>$ Dari pengujian yang telah dilakukan diperoleh hasil bahwa untuk benda uji referensi, benda uji yang diimplantasi dengan ion magnesium $(\mathrm{Mg})$ dan dengan ion yttrium $(\mathrm{Y})$ dengan waktu oksidasi 100 jam laju oksidasinya masing-masing sekitar $0,54 \mathrm{mg} / \mathrm{cm}^{2}, 0,48 \mathrm{mg} / \mathrm{cm}^{2}$ dan $0,40 \mathrm{mg} / \mathrm{cm}^{2}$.

Sedangkan dari analisa struktur mikro potongan melintang terlihat bahwa ketebalan lapisan oksida masing-masing adalah sekitar $0,67 \mu \mathrm{m}, 0,3 \mu \mathrm{m}$ dan 0,25 $\mu \mathrm{m}$.

Dari hasil tersebut dapat disimpulkan bahwa dengan adanya penambahan elemen reaktif magnesium maupun yttrium temyata mampu meningkatkan ketahanan oksidasi material MA 956.

\section{UCAPAN TERIMA KASIH}

Dengan selesainya penelitian ini, penulis menyampaikan terima kasih yang sebanyak- banyaknya kepada yang terhormat Bapak Al. Sunarto, Mudjiono, Slamet Riyadi dan Bapak Sumarmo yang telah banyak membantu dalam penyiapan sample, proses implantasi dan penulisan naskah.

\section{DAFTAR PUSTAKA}

1. KORB, G, Conf. New Materials by Mech. Alloying Techniques (ed. E. Arzt and L. Schulz) DGM, Oberursel, 175,1990 .

2. GESSINGER, G.H., Powder Metallurgy of Supperalloys, Butterworth, London, 1984.

3. ESCUDERO, M.L, GARCIA ALONSO, M.C, RUIZ, J.,AND CANAHUA, H., Effect Of Environmental Changes On The Corrosion Behavior Ojr
A12031MA956 System, Materials and Corrosion 5 L, 434-43 8, 2000.

4. QUADAKKERS, W.J., NAUMENKO, D., SINGHEISER, L., DENKALLA H.J., TYAI, A.K., CZYSKAFILE MONOWICZ, A., Bath To Bath Variations In The Oxidation Behavior Of Alumina forming Fe-based Alloys, Materials and Corrosion , 350 - 357, 2000.

5. JEDLINSKI, J. 1997, The Oxidation Behavior of $\mathrm{FeCr} \mathrm{Al}$ Aluminium Forming Alloys AT High Temperature, Solid State Ionics, 101 - 103, 1033 -1040, 1997.

6. HAANAPPED, V.A.C, STROOSNIJDER, Ion Implantation Technique as Research Tool For Improving Oxidation Behavior Of TiAl Based Intermettalic, Surface Engineering, vol. 15. No.2, 119 - 125, 1999.

7. QUADAKKERS, W.J., MALKOW, I., NICKEL, H., The Effect of Major and Minor Alloying elements On The Oxidation Limited Life of FeCrAl Based Alloys, Procedings of The 21 International Conference On Heat resisting, Gatlinburg Tennes, 91 - 96, 1995. 